\title{
ANALISIS KINERJA KEUANGAN PEMERINTAH DAERAH KABUPATEN KAUR
}

\author{
Muhammad Zuhri \\ Ahmad Soleh \\ Fakultas Ekonomi Universitas Dehasen Bengkulu
}

\begin{abstract}
ABSTRAK
Muhammad Zuhri dan Ahmad Soleh; Salah satu dampak positif dari pelaksanaan otonomi daerah adalah adanya pemekaran daerah provinsi maupun kabupaten/kota yang hampir terjadi di seluruh Indonesia. Salah satu daerah hasil dari pemekaran wilayah adalah Kabupaten Kaur Provinsi Bengkulu. Sebagai kabupaten baru yang tumbuh dimasa otonomi daerah, Kabupaten Kaur memiliki kewenangan untuk mengatur daerahnya sendiri. Tujuan penelitian ini adalah untuk mengetahui Kinerja Keuangan Pemerintah Daerah Kabupaten Kaur. Metode pengumpulan data yang digunakan adalah dokumentasi. Sedangkan metode analisis menggunakan metode kuantitatif dengan menggunakan rasio keuangan. Kinerja Keuangan Pemerintah Daerah Kabupaten Kaur tahun 2001-2014 jika dilihat dari Rasio Kemandirian Keuangan Daerah tergolong rendah sekali (rata-rata 2,44\% per tahun). Rasio Efektivitas PAD diketahui bahwa efektivitas PAD Kabupaten Kaur tahun 2011, 2013 dan 2014 berjalan Kurang Efektif yang ditunjukkan dengan nilai rasio antara 75\%-89\%, namun pada tahun 2012 berjalan sangat efektif dengan nilai rasio mencapai 107,3\%. Rasio Aktivitas dari sisi Rasio Belanja Operasi tergolong baik yakni dengan nilai rasio antara 50\%-100\% atau dengan nilai rata-rata 76,7\% per tahun sedangkan Rasio Belanja Modal tergolong tidak baik karena memiliki nilai rasio kurang dari 50\% atau dengan nilai rata-rata pertahun sebesar 23,2\% per tahun). Pertumbuhan Pendapatan Asli Daerah (PAD) Kabupaten Kaur mengalami peningkatan dari tahun ke tahun, namun pertumbuhan tersebut tergolong pertumbuhan sedang dengan nilai rata-rata pertahun sebesar $45,22 \%$ per tahun.
\end{abstract}

\section{ABSTRACT}

Muhammad Zuhri dan Ahmad Soleh; One positive impact of the implementation of regional autonomy is the expansion of provincial and district / city that almost occurred throughout Indonesia. One area is the result of the expansion area Kaur regency in Bengkulu Province. As a new district that grows future regional autonomy, Kaur District has the authority to manage their own regions. The purpose of this study was to determine the Financial Performance of the District Government Kaur. Data collection method used is documentation. While the method of analysis using quantitative methods using financial ratios. Financial Performance of the District Government Kaur years 2001-2014 when viewed from the Regional Financial Independence Ratio is relatively low once (an average of $2.44 \%$ per year). Effectiveness Ratio PAD is known that the effectiveness of Kaur regency in 2011, 2013 and 2014 runs Ineffective indicated by the value ratio between $75 \%-89 \%$, but in 2012 went very effective with a ratio reached 107.3\%. Activity Ratio of the ratio of Operating Expenditure quite well that the value ratio between 50\% -100\% or the average value of 76.7\% per year, while the ratio of Capital Expenditure classified as not good because it has value ratio is less than 50\% or the average value -rata year by $23.2 \%$ per year). Growth in revenue (PAD) Kaur District has increased from year to year, but the growth was relatively moderate growth with an annual average value of $45.22 \%$ per year.

Key Words: Financial performance, Ratio of Regional Financial Independence, Effectiveness Ratio, Activity Ratio, Growth Ratio, Kabupaten Kaur.

\section{PENDAHULUAN}

Sebagai konsekuensi dari pelaksanaan otonomi daerah, Pemerintah Daerah dituntut melakukan tugasnya dengan baik dan transparan. Otonomi daerah merupakan pemberdayaan daerah dalam pengambilan keputusan daerah secara lebih baik, leluasa untuk mengelola sumber daya yang dimiliki sesuai dengan kepentingan, prioritas dan potensi daerah itu sendiri. Adanya otonomi daerah tersebut pemerintah diberi keluluasaan untuk mengelola sumber daya yang dimiliki sesuai dengan kepentingan, prioritas dan potensi daerah itu sendiri. Adanya otonomi daerah tersebut pemerintah diberi keluluasaan untuk mengelola sumber daya dan mempertanggung jawabkan kepada masyarakat sejalan dengan pelaksanaan otonomi daerah diperlukan adanya sistem desentralisasi secara transparan, efektif dan efisien 
dan dapat dipertanggung jawabkan kepada masyarakat luas. Pertanggung jawaban pemerintah kepada publik yang bersih merupakan tuntutan yang harus dipenuhi oleh pemerintah, dimana untuk mewujudkannya memerlukan media tertentu. Salah satu alat untuk memfasilitasi tercapainya laporan keuangan pemerintah daerah yang kompetitif yaitu laporan keuangan pemerintah daerah tersebut digunakan untuk membandingkan kinerja keuangan yang akurat dengan anggaran, menilai kondisi dan hasil operasional, membantu menentukan tingkat kepatuhan terhadap peraturan perundangan yang terkait dengan masalah keuangan dan ketentuan lainnya serta membantu mengevaluasi tingkat efisien dan efektivitas.

Pengukuran kinerja untuk kepentingan publik dapat dijadikan evaluasi dan memulihkan kinerja dengan pembanding skema kerja dan pelaksanaannya. Selain itu dapat juga digunakan sebagai tolak ukur untuk peningkatan kinerja pemerintah daerah pada periode berikutnya. Pengukuran kinerja dapat menggunakan analisis rasio keuangan daerah terhadap laporan perhitungan anggaran pendapatan dan belanja daerah yang terdiri dari rasio kemandirian keuangan daerah, rasio efektivitas dan efisiensi pendapatan asli daerah, rasio aktivitas, debt service coverage ratio dan rasio pertumbuhan (Halim, 2004: 150). Jadi analisa kinerja keuangan ini sangat penting karena dapat dijadikan pedoman untuk perbaikan kinerja dimasa yang akan datang, menunjukkan arah pencapaian target kinerja yang telah ditetapkan, memonitor dan mengevaluasi kinerja, membantu menungkapkan dan memecahkan masalah yang ada. Terselenggaranya Good Governance merupakan salah satu persyaratan bagi pemerintah dalam mencapai tujuan serta cita-cita berbangsa dan bernegara.

Reformasi pengelolaan keuangan daerah sendiri diawali dengan adanya tuntutan terwujudnya pemerintahan yang baik (good governance). Guna mewujudkan pemerintahan yang baik, diperlukan reformasi kelembagaan dan reformasi manajemen sektor publik. "Reformasi manajemen sektor publik harus dan sangat ditentukan oleh reformasi di bidang pengelolaan keuangan daerah" (Mardiasmo, 2002). Implikasi adanya otonomi daerah dan daerah otonom yang berdasarkan asas desentralisasi telah memberikan dampak positif bagi daerah. Salah satu dampak positif dari pelaksanaan otonomi daerah adalah adanya pemekaran daerah provinsi maupun kabupaten/kota yang hampir terjadi diseluruh Indonesia. Salah satu daerah hasil dari pemekaran wilayah adalah Kabupaten Kaur Provinsi Bengkulu. Dampak dari pemekaran provinsi dan kabupaten/kota, telah banyak terbentuk kecamatan dan kelurahan/desa definitif yang baru. Tujuannya adalah agar pelayanan pemerintah kepada masyarakat dapat lebih efektif dan efisien, serta diharapkan mempercepat pelaksanaan pembangunan. Oleh karena itu, di samping melakukan pembenahan dan peningkatan kualitas sumber daya manusia, pemerintah juga perlu memprioritaskan pemerataan pembangunan hingga ke daerah terpencil seperti di Kabupaten Kaur yang masih tergolong kabupaten tertinggal.

Pada hakikatnya keuangan daerah yang tertuang dalam APBD Kabupaten Kaur merupakan aset milik masyarakat Kabupaten Kaur. Dalam rangka memenuhi prinsip akuntabilitas, Pemerintah Kabupaten Kaur telah menerbitkan Peraturan Bupati Kaur Nomor 50 Tahun 2012 Tentang Sistem Prosedur Pengelolaan Keuangan Daerah Kabupaten Kaur dan Peraturan Bupati Nomor 51 Tahun 2012 tentang Kebijakan Akuntansi. Ketentuan ini mengacu Kepada Peraturan Menteri Dalam Negeri Nomor 13 Tahun 2006 dan Peraturan Menteri Dalam Negeri Nomor 59 Tahun 2007, tentang Perubahan atas Peraturan Menteri Dalam Negeri Nomor 13 Tahun 2006 terakhir di ubah dengan Peraturan Menteri Dalam Negeri Nomor 21 Tahun 2011 tentang Pedoman Pengelolaan Keuangan Daerah. Dengan ketentuan ini, diharapkan agar pengelolaan keuangan daerah maupun APBD dapat mencapai tujuan yang ditetapkan dan dapat memenuhi kebutuhan pihak-pihak terkait dalam pengambilan keputusan. Realisasi Anggaran Kabupaten Kaur Tahun 2011-2014 ditunjukkan pada tabel 1.

Tabel 1. Realisasi Anggaran Kabupaten Kaur Tahun 2011-2014 (Dalam ribuan Rupiah)

\begin{tabular}{|c|c|c|c|c|c|}
\hline \multirow[b]{2}{*}{ No } & \multirow[b]{2}{*}{ URAIAN } & \multicolumn{4}{|c|}{ TAHUN } \\
\hline & & 2011 & 2012 & 2013 & 2014 \\
\hline $\mathbf{A}$ & PENDAPATAN & 365.412 .752 .616 & 430.696 .678 .776 & 416.124.824.876 & 540.039 .995 .763 \\
\hline 1 & Pendapatan Asli Daerah & 6.810 .591 .506 & 7.781 .828 .801 & 10.339 .333 .376 & 19.493.428.861 \\
\hline 2 & Pendapatan Trransfer & 358.602 .161 .109 & 421.914 .849 .974 & 449.785 .491 .500 & 520.046 .566 .901 \\
\hline 3 & Lain-lain Pendapatan yang sah & - & 1.000 .000 .000 & 1.000 .000 .000 & 500.000 .000 \\
\hline B & BELANJA & 355.460 .934 .019 & 416.397.338.772 & 467.213.658.063 & 534.128 .440 .826 \\
\hline 1 & Belanja Operasi & 273.997 .555 .077 & 326.922 .424 .252 & 360.826 .001 .226 & 396.116 .065 .121 \\
\hline 2 & Belanja Modal & 81.463 .378 .942 & 89.474 .914 .520 & 106.387 .656 .837 & 138.012 .375 .705 \\
\hline 3 & Belanja Tak Terduga & - & - & - & - \\
\hline 4 & Transfer & & & - & \\
\hline & Surplus/(Defisit) & 9.951.818.597 & 14.299 .340 .004 & (6.088.883.186) & 5.911 .554 .937 \\
\hline
\end{tabular}

Sumber: DPPKAD Kabupaten Kaur (Data Diolah) 2016 
Berdasar pada tabel 1 di atas, diketahui bahwa realisasi anggaran kabupaten Kaur tahun 20112014 secara umum cenderung mengalami peningkatan, meskipun juga terjadi penurunan pendapatan pada tahun 2013 yang mengakibatkan terjadi defisit anggaran senilai Rp 6.088.883.186. Pendapatan daerah kabupaten Kaur didominasi oleh pendapatan yang bersumber dari pendapatan transfer, sedangkan Pendapatan Asli Daerah (PAD) relatif masih sangat kecil terhadap seluruh total pendapatan. Selanjutnya ditinjau dari aspek belanja daerah yang terdiri atas belanja operasi dan belanja modal, belanja operasi memiliki porsi pengeluaran yang lebih tinggi jika dibanding dengan belanja modal. Realisasi kedua belanja tersebut cenderung mengalami peningkatan di setiap tahun.

Berdasarkan uraian di atas maka penulis tertarik melakukan penelitian dengan judul "Analisis Kinerja Keuangan Pemerintah Daerah Kabupaten Kaur". Analisis Kinerja Keuangan Pemerintah Daerah Kabupaten Kaur dalam penelitian ini adalah suatu proses penilaian mengenai tingkat kemajuan pencapaian pelaksanaan pekerjaan/kegiatan Pemerintah Daerah Kabupaten Kaur dalam bidang keuangan untuk kurun waktu 2011-2014. Rasio yang digunakan oleh peneliti dalam menganalisis kinerja keuangan Pemerintah Daerah Kabupaten Kaur pada penelitian ini adalah Rasio Kemandirian, Rasio efektivitas, Rasio Aktivitas, dan Rasio Pertumbuhan.

\section{LANDASAN TEORI}

\section{Laporan Keuangan Pemerintah Daerah}

Tujuan umum laporan keuangan pemerintah adalah menyajikan kinerja keuangan suatu entitas pelaporan yang bermanfaat bagi para pengguna dalam membuat dan mengevaluasi keputusan mengenai alokasi sumber daya. Secara spesifik tujuan pelaporan keuangan pemerintah adalah untuk menyajikan informasi yang berguna untuk pengambilan keputusan dan untuk menunjukkan akuntabilitas entitas pelaporan atas sumber daya yang dipercayakan kepadanya (SAP No.1, paragraf 9) :

a. Menyediakan informasi mengenai posisi sumber daya ekonomi, kewajiban dan entitas dana pemerintah.

b. Menyediakan informasi mengenai perubahan posisi sumber daya ekonomi, kewajiban dan ekuitas dana pemerintah.

c. Menyediakan informasi mengenai sumber alokasi dan penggunaan sumber daya ekonomi.

d. Menyediakan informasi mengenai ketaatan realisasi terhadap anggarannya.

e. Menyediakan informasi cara entitas pelaporan mendanai aktivitasnya dan memenuhi kebutuhan kasnya.

f. Menyediakan informasi mengenai potensi pemerintah untuk membiayai penyelenggaraan kegiatan pemerintah.

g. Menyediakan informasi yang berguna untuk mengevaluasi kemampuan entitas pelaporan dalam mendanai aktivitasnya.

Tanpa laporan kinerja, laporan keuangan yang disajikan pemerintah akan memberikan informasi yang kurang lengkap kepada penggunanya. Pentingnya informasi surplus dan defisit dalam laporan keuangan pemerintah karena pembiayaan penerimaan mencantumkan adanya penerimaan pinjaman. Ancaman serius apabila informasi dari laporan kinerja tidak dapat disajikan oleh entitas akan menjadikan kebijakan pemerintah menjadi tidak tepat. Contoh utang luar negeri kita yang amat besar merupakan salah satu hasil kebijakan masa lalu yang harus ditanggung oleh generasi sekarang akibat dari pembuat kebijakan keuangan tidak mempertimbangkan informasi surplus/defisit. Informasi surplus/defisit menjadi amat penting dalam upaya mengentaskan bangsa dari jeratan hutang dan dapat menumbuhkan kemandirian.

\section{Kinerja Keuangan Pemerintah Daerah}

Pada dasarnya pengukuran kinerja sektor publik dilakukan untuk memnuhi tiga tujuan yaitu (a) untuk membantu memperbaiki kinerja pemerintah, (b) untuk pengalokasian sumber ddaya dan pembuatan keputusan dan (c) untuk mewujudkan pertanggung jawaban publik dan memperbaiki komunikasi kelembagaan (Mardiasmo, 2002: 121).

Pengukuran kinerja mempunyai manfaat yang besar bagi organisasi, menurut Simamora (2001: 227) secara umum manfaat pengukuran kinerja adalah sebagai berikut :

a. Memberikan pemahaman mengenai ukuran yang telah digunakan menilai kinerja manajemen.

b. Menunjukan arah pencapian target kinerja yang telah ditetapkan.

c. Memonitor dan mengevaluasi kinerja dengan membandingkan skema kerja dan pelaksanaannya.

d. Membantu mengungkapkan dan memecahkan masalah yang ada.

e. Membantu memahami proses kegiatan instansi pemerintah.

f. Memastikan bahwa pengambilan keputusan dilakukan secara objektif. 


\section{Rasio Keuangan Pemerintah Daerah}

Alat rasio keuangan yang digunakan adalah analisis rasio yang dikembangkan berdasarkan data keuangan yang bersumber dari Anggaran Pendapatan Belanja Daerah (Halim, 2014: 267) yaitu:

a. Rasio Kemandirian Keuangan Daerah (RKKD)

Rasio Kemandirian Keuangan Daerah (RKKD) menunjukkan tingkat kemampuan suatu daerah dalam membiayai sendiri kegiatan pemerintah, pembangunan dan pelayanan kepada masyarakat yang telah membayar pajak dan retribusi sebagai sumber pendapatan yang diperlukan daerah. Rasio Kemandirian Keuangan Daerah ditunjukkan oleh besarnya Pendapatan Asli Daerah dibandingkan dengan Pendapatan Daerah yang berasal dari sumber lain (Pendapatan Transfer) antara lain : Bagi hasil pajak, Bagi hasil bukan pajak sumber daya alam, Dana alokasi umum dan Alokasi khusus, Dana darurat dan pinjaman. Rumus yang digunakan untuk menghitung Rasio Kemandirian adalah:

$$
\mathrm{RKKD}=\frac{P A D}{\text { Pendapatan Transfer }} \times 100 \%
$$

Dengan kriteria sebagai berikut:

$\begin{array}{lll}\text { Rendah sekali } & : & 0 \%-25 \% \\ \text { Rendah } & : & 25 \%-50 \% \\ \text { Sedang } & : & 50 \%-75 \% \\ \text { Tinggi } & : & 75 \%-100 \%\end{array}$

b. Rasio Efektivitas Dan Efisiensi Pendapatan Asli Daerah

1) Rasio efektivitas menggambarkan kemampuan pemerintah daerah dalam merealisasikan pendapatan asli daerah yang direncanakan dibandingkan dengan target yang ditetapkan berdasarkan potensi riil daerah. Kemampuan daerah dikategorikan efektif apabila rasio yang dicapai mencapai minimal sebesar 1 (satu) atau 100 persen.

Rasio Efektivitas $=\frac{\text { Realisasi PAD }}{\text { Anggaran } P A D} \times 100 \%$

Dengan kriteria sebagai berikut:

$\begin{array}{lll}\text { Sangat efektif } & : & >100 \% \\ \text { Efektif } & : & 100 \% \\ \text { Cukup efektif } & : & 90 \%-99 \% \\ \text { Kurang efektif } & : & 75 \%-89 \% \\ \text { Tidak efektif } & : & <75 \%\end{array}$

2) Rasio efesiensi adalah rasio yang menggambarkan perbandingan antara besarnya biaya yang dikeluarkan untuk memperoleh pendapatan dengan realisasi pendapatan yang diterima. Untuk itu pemerintah daerah perlu menghitung secara cermat berapa besarnya biaya yang dikeluarkan untuk merealisasikan seluruh pendapatan yang diterimanya sehingga dapat diketahui apakah kegiatan pemungutan pendapatannya tersebut efesien atau tidak. Hal itu perlu dilakukan karena meskipun pemerintah daerah berhasil merealisasikan penerimaan pendapatan sesuai dengan target yang ditetapkan, namun keberhasilan itu kurang memiliki arti apabila ternyata biaya yang dikeluarkan untuk merealisasikan target penerimaan pendapatannya itu lebih besar dari pada realisasi pendapatan yang diterimanya. Kinerja pemerintah daerah dalam melakukan pemungutan pendapatan dikategorikan efisien apabila rasio yang dicapai kurang dari 1 (satu) atau di bawah 100 persen.

Rasio Efesiensi $=\frac{\text { Biaya Yang Dikeluarkan Untuk Memungut PAD }}{\text { Realisasi Penerimaan PAD }} \times 100 \%$

c. Rasio Aktivitas

Rasio Keserasian menggambarkan bagaimana pemerintahan daerah memprioritaskan alokasi dananya pada belanja operasi dan belanja modal secara optimal. Semakin tinggi persentase dana yang dialokasikan untuk belanja operasi berarti persentase belanja modal yang digunakan untuk menyediakan sarana prasarana ekonomi masyarakat cenderung semakin kecil. Secara sederhana, rasio keserasian itu dapat diformulasikan sebagai berikut (Halim 2007:236): 
1) Rasio Belanja Operasi

Rasio Belanja Operasi $=\frac{\text { Total Belanja Operasi }}{\text { Total Belanja Daerah }} \times 100 \%$

2) Rasio Belanja Modal

Rasio Belanja Modal $=\frac{\text { Total Belanja Modal }}{\text { Total Belanja Daerah }} \times 100 \%$

Dengan kriteria sebagai berikut:

Tidak Baik : $\quad 0 \%-50 \%$

Baik : $50 \%-100 \%$

d. Rasio Pertumbuhan

Rasio pertumbuhan (growth Ratio) mengukur seberapa besar kemampuan pemerintah daerah dalam mempertahankan dan meningkatkan keberhasilannya yang dicapai di periode ke periode berikutnya. Rasio pertumbuhan dikatakan baik, jika setiap tahunnya mengalami pertumbuhan positif atau mengalami peningkatan.

Rasio Pertumbuhan $=\frac{R p X n-R p X n-1}{R p X n-1} \times 100 \%$

Keterangan:

RpXn-Xn-1 = Realisasi tahun yang dikurangi tahun sebelumnya.

RpXn-1 = Realisasi penerimaan tahun sebelumnya.

Dengan kriteria sebagai berikut:

Rendah : $\quad 0 \%-25 \%$

Sedang : $\quad 25 \%-50 \%$

Tinggi : $\quad 50 \%-100 \%$

\section{KERANGKA ANALISIS}

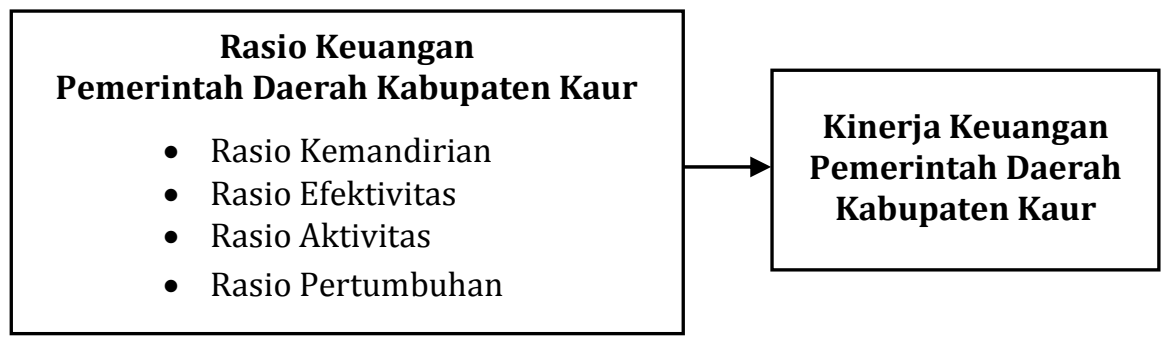

Gambar 1. Kerangka Analisis

\section{PEMBAHASAN}

\section{Analisis Kinerja Keuangan Pemerintah Daerah Kabupaten Kaur}

Analisis Kinerja Keuangan Pemerintah Daerah Kabupaten Kaur dalam penelitian ini adalah suatu proses penilaian mengenai tingkat kemajuan pencapaian pelaksanaan pekerjaan/kegiatan Pemerintah Daerah Kabupaten Kaur dalam bidang keuangan untuk kurun waktu 2011-2014. Rasio yang digunakan oleh peneliti dalam menganalisis kinerja keuangan Pemerintah Daerah Kabupaten Kaur pada penelitian ini adalah: Rasio Kemandirian, Rasio efektivitas, Rasio Aktivitas, dan Rasio Pertumbuhan. Data yang digunakan dalam melakukan penelitian ini adalah Laporan Realisasi Anggaran Pemerintah Kabupaten Kaur yang diperoleh dari Dinas Pendapatan Pengelolaan Keuangan dan Aset Daerah (DPPKAD) Kabupaten Kaur. 
Dari data tersebut akan dapat diketahui Kinerja Keuangan Kabupaten Kaur. Adapun hasil dari analisis Rasio tersebut adalah:

a. Rasio Kemandirian Keuangan Daerah

Rasio Kemandirian Keuangan Daerah menunjukkan tingkat kemampuan suatu daerah dalam membiayai sendiri kegiatan pemerintah, pembangunan dan pelayanan kepada masyarakat yang telah membayar pajak dan retribusi sebagai sumber pendapatan yang diperlukan daerah. Rasio Kemandirian Keuangan Daerah Pemerintah daerah Kabupaten Kaur Periode Tahun 2011-2014 ditunjukkan pada tabel 1.

Tabel 2. Rasio Kemandirian Keuangan Daerah Pemerintah daerah Kabupaten Kaur Periode Tahun 2011-2014

\begin{tabular}{|c|c|c|c|c|}
\hline $\begin{array}{c}\text { Tahun } \\
\text { Anggaran }\end{array}$ & $\begin{array}{c}\text { Pendapatan Asli Daerah } \\
(\mathrm{Rp})\end{array}$ & Pendapatan Transfer (Rp) & $\begin{array}{c}\text { RKKD } \\
(\%)\end{array}$ & Keterangan \\
\hline 2011 & $6.810 .591 .506,25$ & $358.602 .161 .109,90$ & 1,89 & Rendah Sekali \\
\hline 2012 & $7.781 .828 .801,72$ & $421.914 .849 .974,70$ & 1,84 & Rendah Sekali \\
\hline 2013 & $10.339 .333 .376,25$ & $449.785 .491 .500,67$ & 2,29 & Rendah Sekali \\
\hline 2014 & $19.493 .428 .861,87$ & $520.046 .566 .901,34$ & 3,74 & Rendah Sekali \\
\hline
\end{tabular}

Sumber: DPPKAD Kabupaten Kaur (Data Diolah) 2016

Keterangan (\%):

Rendah sekali : $0 \%-25 \%$

Rendah : $25 \%-50 \%$

Sedang $\quad: 50 \%-75 \%$

Tinggi : $75 \%-100 \%$

Pada Tabel 2 menunjukan bahwa PAD Kabupaten Kaur dari tahun 2011 sampai dengan 2014 mengalami penurunan dan kenaikan. Pada tahun 2011 PAD Kabupaten Kaur sebesar Rp 6.810.591.506,25 atau sebesar 1,89\% dari total pendapatan. Mengalami kenaikan pada tahun 2012 yaitu menjadi $\mathrm{Rp} 7.781 .828 .801,72$ atau sebesar 1,84\% dari total pendapatan. Pada tahun 2013 PAD Kabupaten Kaur mengalami kenaikan menjadi Rp 10.339.333.376,25 atau sebesar 2,29\% dari total pendapatan. Kemudian pada tahun 2014 mengalami kenaikan yaitu sebesar Rp 19.493.428.861,87 atau $3,74 \%$ dari total pendapatan.

Berdasarkan hasil perhitungan pada tabel 1 kemampuan keuangan Pemerintah Daerah Kabupaten Kaur tergolong masih sangat rendah dan pola hubungannya termasuk pola hubungan Instruktif dimana peranan pemerintah pusat lebih dominan dari pada kemandirian pemerintah daerah (daerah yang tidak mampu melaksanakan otonomi daerah). Terjadi kenaikan maupun penurunan dari tahun 2011 sampai tahun 2014. Berawal pada tahun 2011 Rasio Kemandirian sebesar 1,89\%, kemudian turun menjadi 1,84\% pada tahun 2012. Pada tahun 2013 Rasio Kemandirian naik sebesar 2,29\%. Pada tahun 2014 terjadi kenaikan menjadi 3,74\%.

Menurut uraian di atas dapat disimpulkan bahwa Rasio Kemandirian Keuangan Daerah selama empat tahun pada Pemerintah Kabupaten Kaur memiliki rata-rata kemandiriannya masih tergolong rendah dan dalam kategori kemampuan keuangan kurang dengan pola hubungan Instruktif yaitu peranan pemerintah pusat masih sangat dominan dibandingkan pemerintah daerah, ini dapat dilihat dari Rasio Kemandirian Keuangan Daerah masih tergolong dalam interval 0\% - 25\%. Rasio Kemandirian yang masih rendah mengakibatkan kemampuan keuangan daerah Kabupaten Kaur dalam membiayai pelaksanaan pemerintahan dan pembangunan daerah masih sangat tergantug bantuan dari pemerintah pusat. Jadi Kemandirian Keuangan Pemerintah Daerah Kabupaten Kaur secara keseluruhan dapat dikatakan sangat rendah sekali, hal ini menggambarkan bahwa tingkat ketergantungan daerah terhadap sumber dana ekstern masih sangat tinggi.

\section{b. Rasio Efektivitas Pendapatan Asli Daerah}

Rasio Efektivitas menggambarkan kemampuan Pemerintah Daerah dalam merealisasikan PAD yang direncanakan dibandingkan dengan target yang ditetapkan berdasarkan potensi riil daerah. Semakin tinggi rasio efektivitas, maka semakin baik kinerja pemerintah daerah. Rasio Efektivitas Pendapatan Asli Daerah Pemerintah daerah Kabupaten Kaur Periode Tahun 2011-2014 ditunjukkan pada tabel 3. 
Tabel 3. Rasio Efektivitas Pendapatan Asli Daerah Pemerintah daerah Kabupaten Kaur Periode Tahun 2011-2014

\begin{tabular}{|c|c|c|c|c|}
\hline $\begin{array}{c}\text { Tahun } \\
\text { Anggaran }\end{array}$ & $\begin{array}{c}\text { Anggaran PAD } \\
(\mathrm{Rp})\end{array}$ & $\begin{array}{c}\text { Realisasi PAD } \\
(\mathrm{Rp})\end{array}$ & $\begin{array}{c}\text { RE } \\
(\%)\end{array}$ & Keterangan \\
\hline 2011 & $8.796 .237 .030,28$ & $6.810 .591 .506,25$ & 77,7 & Kurang Efektif \\
\hline 2012 & $7.246 .629 .500,00$ & $7.781 .828 .801,72$ & 107,3 & Sangat Efektif \\
\hline 2013 & $11.869 .898 .057,16$ & $10.339 .333 .376,25$ & 87,1 & Kurang Efektif \\
\hline 2014 & $22.130 .076 .402,23$ & $19.493 .428 .861,87$ & 88 & Kurang Efektif \\
\hline
\end{tabular}

Sumber: DPPKAD Kabupaten Kaur (Data Diolah) 2016

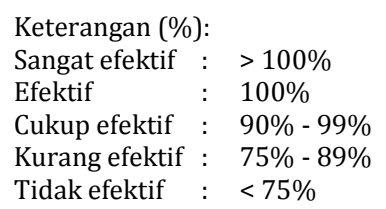

Berdasarkan perhitungan pada tabel 3 menunjukan bahwa anggaran PAD Kabupaten Kaur relatif mengalami kenaikan dari tahun ke tahun. Pada tahun 2011 PAD dianggarkan sebesar Rp 8.796.237.030,28. Pada tahun 2012 anggaran PAD turun menjadi Rp 7.246.629.500. Pada tahun 2013 PAD dianggarkan naik sebesar Rp 11.869.898.057,16. Pada tahun 2014 anggaran PAD kembali naik menjadi Rp 22.130.076.402,23. Berdasarkan perhitungan pada tabel 2 dapat diketahui bahwa Efektivitas PAD Keuangan Pemerintah Daerah Kabupaten Kaur pada tahun 2011 sebesar 77,7\%, tahun 2012 sebesar 107,3\%, tahun 2013 sebesar 87,1\%, dan tahun 201 sebesar 88\%. Efektivitas kinerja keuangan Kabupaten Kaur untuk tahun 2011, 2013 dan 2014 berjalan Kurang Efektif karena efektivitasnya masih dibawah 100\% . Untuk tahun 2012 sudah Efektif karena nilai yang diperoleh sudah lebih dari 100\%. Menurut uraian dan hasil perhitungan pada tabel 2 Efektivitas Kinerja Keuangan Kabupaten Kaur Masih Cukup Efektif karena rata-rata efektivitasnya 90,02\%. Hal ini disebabkan karena penerimaan dari sektor pajak dan retribusi daerah melebihi dari yang dianggarkan sebelumnya.

\section{Rasio Aktivitas}

Rasio Aktivitas menggambarkan bagaimana pemerintahan daerah memprioritaskan alokasi dananya pada belanja operasi dan belanja modal secara optimal. Rasio Aktivitas Belanja Pemerintah daerah Kabupaten Kaur Periode Tahun 2011-2014 ditunjukkan pada tabel 4 dan 5.

Tabel 4. Rasio Belanja Operasi Pemerintah daerah Kabupaten Kaur Periode Tahun 2011-2014

\begin{tabular}{|c|c|c|c|c|}
\hline $\begin{array}{c}\text { Tahun } \\
\text { Anggaran }\end{array}$ & $\begin{array}{c}\text { Total Belanja } \\
(\mathrm{Rp})\end{array}$ & $\begin{array}{c}\text { Belanja Operasi } \\
(\mathrm{Rp})\end{array}$ & $\begin{array}{c}\text { RBO } \\
(\%)\end{array}$ & Keterangan \\
\hline 2011 & 355.460 .934 .019 & 273.997 .555 .077 & 77 & Baik \\
\hline 2012 & 416.397 .338 .772 & 326.922 .424 .252 & 78,5 & Baik \\
\hline 2013 & 467.213 .658 .063 & 360.826 .001 .226 & 77,2 & Baik \\
\hline 2014 & 534.128 .440 .826 & 396.116 .065 .121 & 74,1 & Baik \\
\hline
\end{tabular}

Sumber: DPPKAD Kabupaten Kaur (Data Diolah) 2016

Keterangan (\%):

Tidak Baik : $\quad 0 \%-50 \%$

Baik : $50 \%-100 \%$

Berdasarkan hasil perhitungan pada tabel 4 di atas diketahui bahwa rata-rata Rasio Aktivitas Belanja Operasi DPPKAD Kabupaten Kaur 76,7\%. Dimulai pada tahun 2011 di mana rasionya sebesar 77\% meningkat pada tahun 2012 menjadi 78,5\%, dan mengalami penurunan menjadi 77,2\% pada tahun 2013 dan pada tahun 2014 mengalami peningkatan menjadi 74,1\%.

Tabel 5. Rasio Belanja Modal Pemerintah daerah Kabupaten Kaur Periode Tahun 2011-2014

\begin{tabular}{|c|c|c|c|c|}
\hline $\begin{array}{c}\text { Tahun } \\
\text { Anggaran }\end{array}$ & $\begin{array}{c}\text { Total Belanja } \\
(\mathrm{Rp})\end{array}$ & $\begin{array}{c}\text { Belanja Operasi } \\
(\mathrm{Rp})\end{array}$ & $\begin{array}{c}\text { RBM } \\
(\%)\end{array}$ & Keterangan \\
\hline 2011 & 355.460 .934 .019 & 81.463 .378 .942 & 22,9 & Tidak Baik \\
\hline 2012 & 416.397 .338 .772 & 89.474 .914 .520 & 21,4 & Tidak Baik \\
\hline 2013 & 467.213 .658 .063 & 106.387 .656 .837 & 22,7 & Tidak Baik \\
\hline 2014 & 534.128 .440 .826 & 138.012 .375 .705 & 25,8 & Tidak Baik \\
\hline
\end{tabular}

Sumber: DPPKAD Kabupaten Kaur (Data Diolah) 2016

Keterangan (\%):

Tidak Baik : $0 \%-50 \%$

Baik : $\quad 50 \%-100 \%$ 
Berdasarkan hasil perhitungan pada tabel 5 di atas diketahui bahwa rata-rata Rasio Aktivitas Belanja Modal Pemerintah Daerah Kabupaten Kaur adalah 23,2\%. Dimulai pada tahun 2011 dimana rasionya sebesar 22,9\% mengalami penurunan pada tahun 2012 menjadi 21,4\%, kemudian mengalami peningkatan menjadi 22,7\% pada tahun 2013. Tahun 2014 juga mengalami peningkatan menjadi $25,8 \%$.

Menurut uraian dan perhitungan di atas bahwa sebagian besar dana yang dimiliki Pemerintah Daerah masih diprioritaskan untuk kebutuhan belanja operasi sehingga rasio belanja modal relatif kecil. Ini dapat dibuktikan dari rata-rata rasio belanja operasi yang masih besar dibandingkan dengan rata-rata rasio belanja modal. Besarnya alokasi dana untuk belanja operasi terutama dikarenakan besarnya dinasdinas otonomi dan belanja pegawai untuk gaji PNS. Dengan ini dapat menunjukkan bahwa Pemerintah Kabupaten Kaur yang lebih condong pada pengeluaran-pengeluaran rutin untuk pemenuhan aktivitas Pemerintahan dan belum memperhatikan pembangunan daerah. Hal ini dikarenakan belum ada patokan yang pasti untuk belanja modal, sehingga Pemerintah Daerah masih berkonsentrasi pada pemenuhan belanja operasi yang mengakibatkan belanja modal untuk Pemerintah Kabupaten Kaur kecil atau belum terpenuhi.

\section{c. Rasio Pertumbuhan}

Rasio pertumbuhan (growth ratio) Halim (2007:128) rasio pertumbuhan dimaksudkan untuk mengukur seberapa besar kemampuan pemerintah daerah dalam mempertahankan dan meningkatkan keberhasilannya yang dicapai dari periode ke periode berikutnya. Rasio pertumbuhan dikatakan baik, jika setiap tahunnya mengalami pertumbuhan positif atau mengalami peningkatan. Rasio Pertumbuhan Pemerintah daerah Kabupaten Kaur Periode Tahun 2011-2014 ditunjukkan pada gambar 2 .

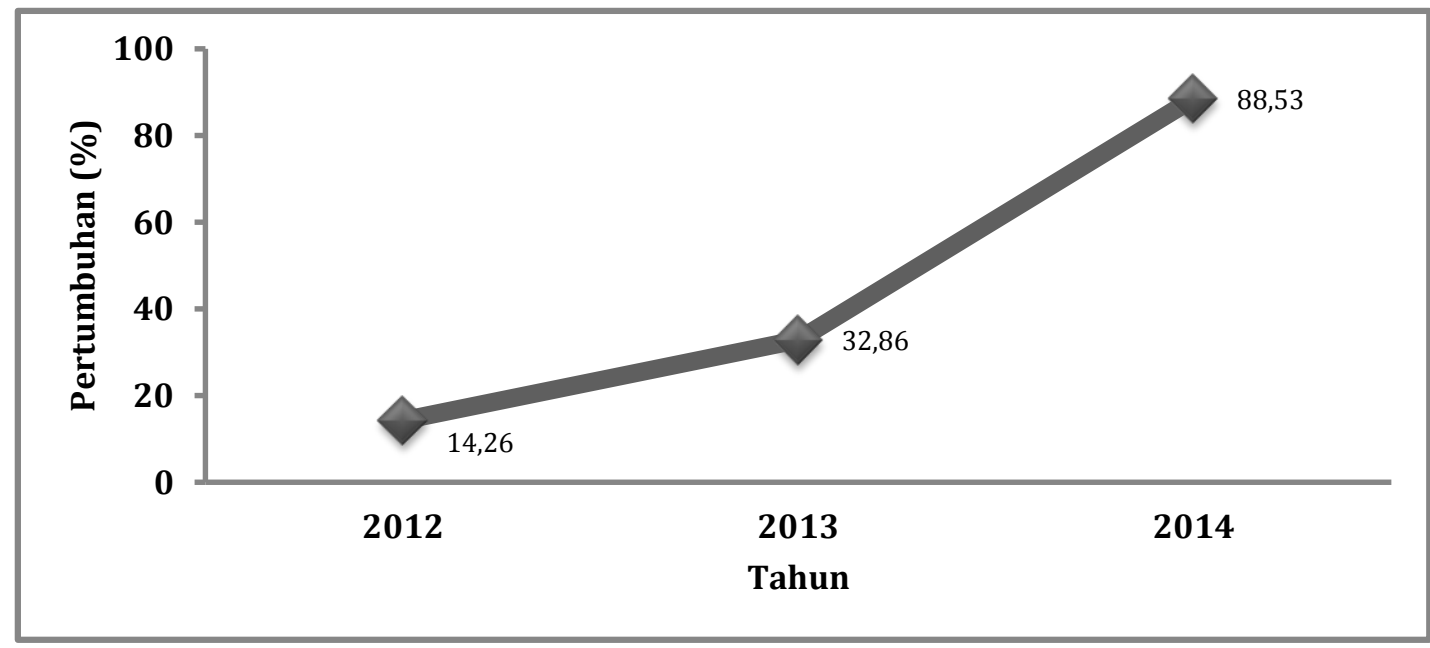

Sumber: DPPKAD Kabupaten Kaur (Data Diolah) 2016

Gambar 2. Pertumbuhan Pemerintah daerah Kabupaten Kaur Periode Tahun 2011-2014

Dari perhitungan rasio pertumbuhan mengukur seberapa besar kemampuan pemerintah daerah dalam mempertahankan dan meningkatkan keberhasilannya yang telah dicapai dari periode ke periode berikutnya. Dari gambar 2 menunjukkan bahwa pertumbuhan Pendapatan Asli Daerah (PAD) dari tahun 2011 ke tahun 2012 hanya mencapai 14,26\% dengan kategori pertumbuhan yang rendah, artinya bahwa potensi yang ada pada sumber-sumber Pendapatan Asli Daerah (PAD) yang meliputi: pajak daerah, retribusi daerah, laba BUMD serta pendapatan lain-lain yang sah belum dikelola secara maksimal. Jika dilihat pertumbuhan Pendapatan Asli Daerah (PAD) tahun 2013 sebesar 32,86\%, ini berarti bahwa terjadi kenaikan sebesar 18,6\%. Pertumbuhan Pendapatan Asli Daerah (PAD) pada tahun 2014 sudah jauh lebih baik diakibatkan oleh pertumbuhan ekonomi masyarakat semakin membaik sehingga terjadi kesadaran masyarakat dalam membayar kewajiban sebagai wajib pajak serta membayar retribusi atas penggunaan jasa-jasa fasilitas pemerintah daerah. Namun jika dilihat pertumbuhan Pendapatan Asli Daerah (PAD) dari tahun 2012 sampai dengan tahun 2013 terlihat bahwa terjadi peningkatan, dan hal tersebut juga diikuti pertumbuhan Pendapatan Asli Daerah (PAD) pada tahun 2014. Kondisi ini diakibatkan oleh meningkatnya pengelolaan pendapatan asli daerah pada sektor laba BUMD serta pendapatan lain-lain yang sah milik pemerintah daerah, namun variabel pajak daerah serta retribusi menjadi sumber utama. 


\section{KESIMPULAN}

Berdasarkan pembahasan di atas, dapat ditarik simpulan sebagai berikut: (1) Kinerja Keuangan Pemerintah Daerah Kabupaten Kaur jika dilihat dari Rasio Kemandirian Keuangan Daerah tergolong rendah sekali dan pola hubungannya termasuk pola hubungan Instruktif, karena masih tergolong dalam interval 0\%-25\%. Berturut-turut dari tahun 2011 sampai dengan 2014 rasionya masing-masing sebesar: 1,89\%; 1,84\%; 2,29\%; dan 3,74\%. (2) Kinerja Keuangan Pemerintah Daerah Kabupaten Kaur jika dilihat dari Rasio Efektivitas PAD diketahui bahwa efektivitas keuangan Pemerintah Daerah Kabupaten Kaur tahun 2011, 2013 dan 2014 berjalan Kurang Efektif yang ditunjukkan dengan nilai rasio antara 75\%-89\% secara berturut-turut sebesar 77,7\%, 87,1\% dan 88\%, namun pada tahun 2012 berjalan sangat efektif dengan nilai rasio mencapai 107,3\%. (3) Rasio Aktivitas dari sisi Rasio Belanja Operasi tergolong baik yakni dengan nilai rasio antara 50\%-100\% atau dengan nilai rata-rata 76,7\% per tahun sedangkan Rasio Belanja Modal tergolong tidak baik karena memiliki nilai rasio kurang dari 50\% atau dengan nilai rata-rata pertahun sebesar 23,2\% per tahun). (4) Pertumbuhan Pendapatan Asli Daerah (PAD) di Kabupaten Kaur mengalami perkembangan dari tahun ke tahun dengan kategori pertumbuhan rendah $(14,26 \%)$ untuk tahun 2012, namun rasio pertumbuhan pada tahun 2013 mengalami peningkatan yakni dengan kategori pertumbuhan sedang (32,86\%), dan di tahun 2014 kembali mengalami peningkatan dengan kategori pertumbuhan tinggi $(88,53 \%)$ sehingga selama periode pengamatan, pertumbuhan tersebut tergolong pertumbuhan sedang dengan nilai rata-rata pertahun sebesar $45,22 \%$ per tahun.

\section{SARAN}

Pemerintah Daerah harus mampu mengoptimalkan penerimaan dari potensi pendapatan yang telah ada. Inisiatif dan kemauan Pemerintah Daerah sangat diperlukan dalam upaya peningkatan PAD. Peningkatan PAD dapat dilakukan Pemerintah Daerah dengan cara melaksanakan secara optimal pemungutan pajak dan retribusi daerah serta melakukan pengawasan dan pengendalian secara sistematis dan berkelanjutan untuk mengantisipasi terjadinya penyimpangan dalam pemungutan PAD oleh aparatur daerah. Selain itu Pemerintah Daerah harus mencari alternatif-alternatif yang memungkinkan untuk dapat mengatasi kekurangan pembiayaannya, dan hal ini memerlukan kreativitas dari aparat pelaksanaan keuangan daerah untuk mencari sumber-sumber pembiayaan baru baik melalui program kerjasama pembiayaan dengan pihak swasta dan juga program peningkatan PAD, misalnya pendirian BUMD sektor potensial. Selain itu Pemerintah Daerah diharapkan dapat mengurangi ketergantungannya terhadap bantuan dari pemerintah pusat.

\section{DAFTAR PUSTAKA}

Halim, Abdul. (2004). Bunga Rampai Manajemen Keuangan Daerah. Edisi Revisi. Yogyakarta: YKPN

. (2007). Akuntansi Sektor Publik Akuntansi Keuangan Daerah. Edisi Revisi. Jakarta: Salemba Empat

(2014). Akuntansi Keuangan Daerah Akuntansi Sektor Publik. Edisi Empat. Jakarta: Salemba Empat

Mardioasmo. (2002). Otonomi dan Manajemen Keuangan Daerah. Yogjakarta: Penerbit Budi

Standar Akuntansi Pemerintah (SAP)

Simamora, Henry. (2001). Manajemen Sumber Daya Manusia. Edisi Kedua. Yogyakarta: STIE YKPN

Undang-Undang Nomor 5 Tahun 1974 Tentang Pokok-Pokok Pemerintah Daerah

Undang-Undang Nomor 23 Tahun 2004 Tentang Sumber Pendapatan Daerah 